\title{
A fogyasztói bizalomérzet befolyásoló tényezői az e-kereskedelemben
}

\author{
Csonka-Ambrus Ágnes \\ Szegedi Tudományegyetem
}

\begin{abstract}
A TANULMÁNY CÉLJA
A virtuális világban létrejövő adás-vételek során a fizikai kontextus minden formája hiányzik, ami a bizalmi tényezők felértékelését eredményezte. Tanulmányomban azt vizsgálom, hogy az online piacterek terén melyek napjainkban - az online kereskedelem két évtizedes berobbanását követően - azok a bizalmi tényezők, melyek képesek helyettesíteni a fizikai kapcsolatot és ezzel növelni a fogyasztó kereskedőbe vetett bizalmát.
\end{abstract}

\begin{abstract}
ALKALMAZOTT MÓDSZERTAN
Lee és Turban (2001) javasolt modellje alapján azt vizsgálom, hogy mik a fogyasztói bizalomérzet befolyásoló tényezői az online kereskedelemben. A szerzőpáros négy fỏ területet határoz meg: internetes kereskedő megbízhatósága; a virtuális vásárlási közeg megbízhatósága; infrastrukturális tényezők és egyéb tényezők. Ezeket a változókat az egyéni fogyasztó bizalom-hajlandósága moderálja.
\end{abstract}

\section{LEGFONTOSABB EREDMÉNYEK \\ Az elektronikus vásárlások során kialakuló bizalomérzetet leginkább az e téren hosszú évek alatt összegyüjtött tapasztalat tudja befolyásolni. A digitális eszközök széleskörü elterjedése pedig lehetővé tette a technikai kompetenciák kialakulását, ami ugyancsak jelentősen megnöveli a vásárlás során a fogyasztó e-kereskedőbe vetett bizalmát. A gyakorlati tapasztalatot csak részben tudják egyes bizalmi tényezők (feed- back-es értékelés, telefonos ügyfélszolgálat stb.) pótolni. Ezek hiánya esetén a harmadik fél (hivatal vagy nemzetközileg elismert szervezet) által kiadott tanúsítvány webáruház nyitó oldalán való feltüntetése képes lehet ezt helyettesíteni, azaz növelni a fogyasztó kereskedőbe vetet bizalmát.}

\section{GYAKORLATI JAVASLATOK}

A kutatási eredmények alapján úgy vélem, hogy egy webáruház lehetséges vásárlóinak bizalmát úgy tudja leginkább elnyerni, ha lehetővé teszi a vásárlói tapasztalatok közlését például különböző árösszehasonlító oldalakon, illetve részletes leírással látja el termékeit és lehetővé teszi a fogyasztók számára a telefonos elérhetőséget is.

Kulcsszavak: e-kereskedelem, fogyasztói bizalom, fogyasztói magatartás

DOI: 10.15170/MM.2020.54.03.04 


\section{BEVEZETÉS INTRODUCTION}

„A viharosan fejlödö, határtalan világhálón szervezödö piacterek bonyolult rendszerek, amelyek, szabályozása, áttekintése, a rajtuk való biztonságos közlekedés számos, ma még megválaszolatlan, kérdést vet fel. Valójában azonban még a legegyszerübb piaci ügylet is magában rejti a bizonytalanság, illetve a kockázat elemét. Ahhoz tehát, hogy a csere egyáltalában megvalósulhasson, szükség van bizalomra."

(Szabó - Hámori 2006, 190)

A digitális forradalom a gazdaság számos területét átalakította, köztük a kiskereskedelmet. A mobilkommunikációs eszközök elmúlt egy-két évtizedben mutatott rohamos technológiai fejlődése és elterjedése a fogyasztást jelentősen átformálta. Ezt mi sem igazolja jobban, mint hogy a Központi Statisztikai Hivatal adatai szerint, míg 2000-ben a kiskereskedelmi forgalmon belül az online értékesítés mindössze 10344 millió forint volt, 2010-ben 46029 millió forint, 2019-ben pedig már 746209 millió forintot számszerüsítettek.

Az elektronikus piacok megjelenésével új megvilágításba kerül a piaci múködés számos, korábban már ismert, ám elhanyagoltan kezelt kategóriája. Ilyen többek között a viselkedési közgazdaságtan képviselői által tárgyalt „bizalom” tényező. Minél nagyobb a fogyasztó részéről az e-kereskedelembe vetett bizalom szintje, annál gyakoribbak az online vásárlásai (Aranyossy - Magisztrák 2016).

Tanulmányomban Lee és Turban (2001) javasolt modellje alapján azt vizsgálom, hogy melyek a fogyasztói bizalomérzet befolyásoló tényezők az elektronikus kereskedelemben. Ennek tükrében, tanulmányommal fô célom rámutatni arra, hogy az online piactereken mely tényezőknek van jelentösége a fogyasztó bizalmának növelése érdekében. Vizsgálati módszernek a mélyinterjút választottam annak érdekében, hogy olyan esetleges tényezök is a felszínre kerülhessenek, melyekkel a szakirodalom eddig még nem foglalkozott. A kutatási eredmények rávilágítanak arra, hogy a fogyasztói bizalomérzet kiépítése igen fontossá vált és egyben felértékelődött, mivel az elektronikus kereskedelemben a felek jellemzően soha nem lépnek egymással fizikális kapcsolatba, a megrendelés, a kommunikáció, a fizetés mind digitálisan történik, így a személyes kontaktus hiányát a bizalomérzett igyekszik pótolni.

\section{SZAKIRODALMI ÁTTEKINTÉS LITERATURE REVIEW}

Hámori (2003) úgy véli, hogy első megközelítésben a bizalom ellentétben áll a piacgazdaság racionális logikájával, amely a személyek közötti bizalmat és szoros kapcsolatokat a dolgok viszonyával és e viszony tárgyszerü, szerződéses körül bástyázásával helyettesíti. A kapitalista piacgazdaságban megszokottá vált, hogy szigorú jogszabályi keretekkel igyekeztek szabályozni a kereskedelmet, így a szerződések arra szolgáltak, hogy feleslegessé tegyék a bizalmat. Az információs társadalomban azonban felértékelődött a bizalom szerepe, ami részben azzal is magyarázható, hogy a piac szereplöi sok esetben áttekinthetetlenek, ellenőrizhetetlenek, illetve a digitális identitásból eredendően nem feltétlen valósak.

A számítógépeknek, a vizualizációs technikáknak, de föleg a digitális azonosításnak köszönhetően úgy lehet az ember valahol, hogy valójában fizikálisan nincs is ott; úgy vehet fel valaki egy személyiséget, hogy nem is hasonlít rá (Balogh 2006). Ez nemcsak emberre igaz, hanem teljes mértékben igaz lehet a gazdasági szervezetekre is. A virtuális identitás létfontosságú, de elszakítható tulajdonosától. Ez a tény, illetve az ebből fakadó félelem szinte már logikusan és magától értetödően válik nyugati technofil kultúránk alapelemévé (Bányai - Novák 2011). A digitális környezetben távol kerülünk az információ és a tárgyak forrásától. Eltávolodunk a megfogható világtól, melyből eredendően megnövekszik a bizalom és a megbízhatóság szerepe (Gere 2004). Ugyanakkor, az online megtévesztést elősegíti, hogy a legtöbb felhasználó úgy véli, hogy a technológia nagyobb biztonsággal jár és nyugodtabban bíznak meg másokban elvégre a különböző adatvédelmi törvények is ezt igyekeznek biztosítani. Ráadásul a megtévesztést még az is könnyebbé teszi, hogy a felek nem találkoznak személyesen, csak esetleg virtuálisan, de a megtévesztők igyekeznek elkerülni a virtuális találkozásokat (pl. videó beszélgetés) (Iványi 2015).

Kérdés csupán csak az, hogy az online megjelenő vállalkozások felismerik-e, hogy digitális sikerükhöz elengedhetetlenné vált a bizalom kiépítése a fogyasztókban. Ellenkező esetben, azaz bizalom nélkül az online jelenlét nem fogja meghozni a várt gazdasági sikereket. Ezt a feltevést alátámasztja Aranyossy és Magisztrák (2016) tanulmánya is, mellyel a szerzőpáros rávilágít arra, hogy a technológiával kapcsolatos bizalmatlanság problémája még nem tekinthető megoldottnak, mivel a 30 év alatti és az átlagosnál erősebb internetes jártasságú 
személyeknek mindössze kétharmada jellemezte magát a semlegesnél nagyobb e-kereskedelmi bizalommal.

A bizalom elöállítása az online piacokon is hasonlóan történik, mint a hagyományos kereskedelemben. Zucker (1986) szerint a bizalom előállításának három típusa határozható meg:

- Folyamat alapú: A bizalom a múlthoz vagy az elvárt cseréhez kötött.

- Tulajdonság alapú: A bizalom személyhez kötött és olyan tulajdonságoktól függ, mint a közös családi háttér, vallás vagy az etnikum. Alapja a társadalmi hasonlóság, a partnerek ugyanahhoz a társadalmi csoporthoz, közösséghez tartoznak.

- Intézményi alapú: A bizalom formális társadalmi struktúrákhoz kötött. Ebben az esetben a bizalom megléte vagy hiánya egyéni vagy cég specifikus sajátosságoktól függ (pl. egyénhez kötött a megfelelő végzettség megléte, céghez kötött sajátosság lehet a hatósági engedélyek, azonosítók megléte).

Sok hasonlóság lelhető fel az online és az offline bizalmi kapcsolatok között, azonban a különbségek is nyilvánvalók. Az online magánszemélyekkel (fogyasztókkal) vagy szervezetekkel (kereskedőkkel) folytatott bizalmi kapcsolatot kiegészíti az internet és a harmadik felek szervezeteibe (pl. fizetési rendszer, futárszolgálat stb.) vetett bizalom. Számos online bizalmi interakciót a személyes kapcsolat hiánya, az egyes felek számára rendelkezésre álló információk aszimmetriája és az adatvédelmi aggályok jellemzik (Beldad et al. 2010). Ez utóbbit a legtöbb ország megfelelő szervei igyekeznek minél pontosabban szabályozni, felismerve, hogy a virtuális világban a bizalom kiépítéséhez teljesen más eszközökhöz kell nyúlni, mint ami a hagyományos kereskedelemben megszokottá, elfogadottá vált.

Az online kereskedelem elterjedésének kezdeti időszakában a bizalom kérdése a világhálón a technikai biztonság problémájaként jelent meg (Hámori 2004). Kutatási eredmények mutattak rá arra, hogy az online információs adatvédelem kulcsfontosságú probléma a digitális fogyasztó számára (Grant \& Waite 2013). Ezt a problémát kívánta enyhíteni az 1996-ban megalkotott Uncitral - kódex jellegü - mintatörvény és a Gazdasági Együttműködési és Fejlesztési Szervezet (OECD) által megfogalmazott irányelvek és akciótervek, melyek komoly hatással voltak többek között az Európai Unió jogalkotására. Az akcióterv a feladatokat négy alapvető csoportba sorolta: (1) a fogyasztók bizalmának megnyerése; (2) a digitális piacok alapvető szabá- lyozási rendszerének kialakítása; (3) az elektronikus kereskedelem információs infrastruktúrájának felgyorsítása mellett a kiszámítható és biztonságos elektronikus kereskedelem feltételeinek megteremtése; (4) „az előnyök maximalizálásának” meghirdetésével a kormányok feladatkörének kijelölése (Verebics 2001).

A törvényi szabályozás azonban csak részben tudja a piaci szereplők közti bizalmat megerősíteni vagy úgy is mondhatnánk, hogy a bizalmatlanságot enyhíteni, mivel a világháló globális mérete igencsak megnehezíti a gazdasági szereplők számára a tranzakciók környezetének és valódiságának feltérképezését (Hámori 2004). A szervezeti szintű kutatások arra az eredményre jutottak, hogy a bizalom átváltozhat úgymond offline módból online módba, ha a fogyasztó meg tud győződni arról, hogy az online szolgáltatást nyújtó szervezetnek van fizikai elérhetősége is (Stewart 2003).

A kockázatokkal és sebezhetőségekkel szemben számos rendszerszintű jelzés került kiépítésre a virtuális világban, melyek fontosak mind az egyéni, mind pedig a szervezeti szintü bizalom kiépítése során azáltal, hogy biztonságot nyújtanak, és csökkentik a bizonytalanság érzetét. Tehát a virtuális világ kiszélesedése egyre inkább felszínre hozta a bizalom fontosságát, ami elsősorban a fizikális kapcsolat hiányából ered.

\section{A FOGYASZTÓI BIZALOM- ÉRZETET BEFOLYÁSOLÓ TÉNYEZŐK MEGISMERÉSÉNEK MÓDSZERTANA METHODS OF LEARNING ABOUT THE FACTORS THAT INFLUENCE THE CONSUMER'S SENSE OF TRUST}

Ahogy a fentiekben már leírásra került, a bizalom - szemben a hagyományos kereskedelemmel - az online kereskedelem egyik kulcstényezőjévé vált. Ebből fakadóan napjainkban már a szakirodalomban is egyre több modellel lehet találkozni, melyek a fogyasztók bizalmához vezető utat igyekeznek feltárni a virtuális világban. Ilyen modell többek között Lee és Turban (2001) korábbi kutatásokon és online kereskedőkkel folytatott beszélgetéseken alapuló modellje a fogyasztói bizalomérzet tényezőinek vizsgálatához (1. ábra). Széleskörü kutatómunkájuknak köszönhetően jelenleg ez az egyik leginkább elfogadott modell a szakirodalomban. A következökben Lee és Turban (2001) modelljének logikája mentén kerül bemutatásra, mely 
tényezők képesek befolyásolni napjainkban a fogyasztói bizalomérzetet az elektronikus kereskedelemben. A szerzőpáros modellje kvantitatív kutatásra épül, azonban úgy vélem, hogy a modellt alapul véve egy kvalitatív kutatás olyan esetleges tényezőket is a felszínre tud hozni, melyekkel a szakirodalom eddig még nem foglalkozott.

\section{1. ábra: Javasolt modell a fogyasztók bizalmához az internetes vásárlásban Figure 1. Proposed model for consumers' trust in online shopping}

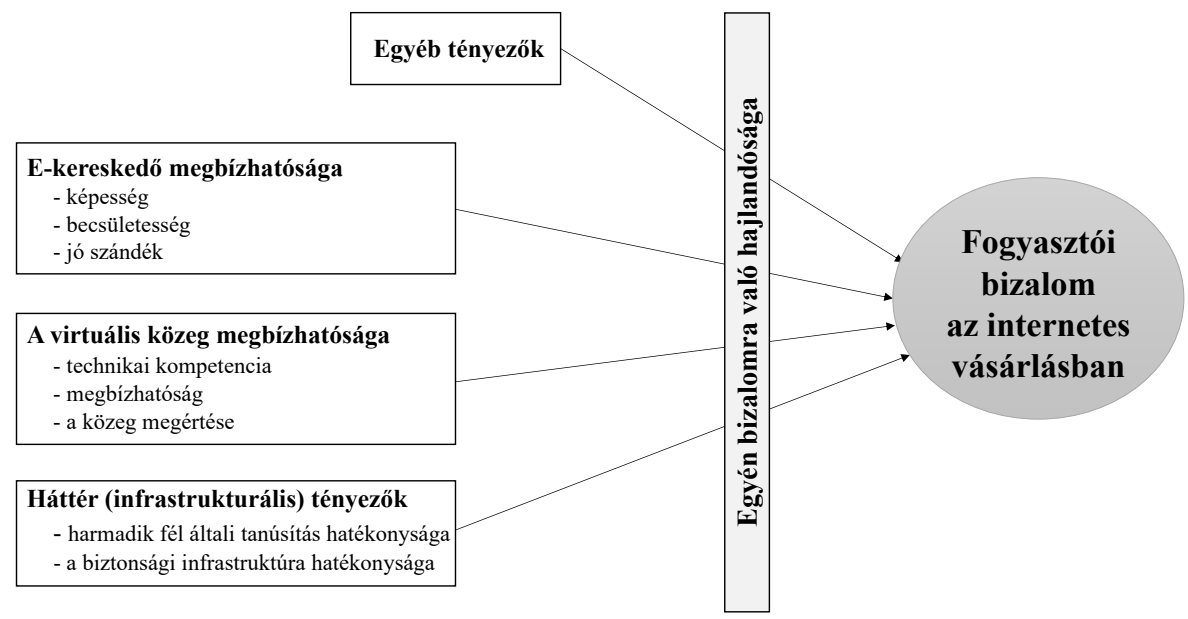

Forrás: Lee \& Turban 2001, 80 alapján saját szerkesztés

Lee és Turban az internetes vásárlás kapcsán több vizsgálatot is folytatott a fogyasztói bizalom jellegének megismerése érdekében, mellyel céljuk egy olyan modell kidolgozása volt, ami visszatükrözi az elektronikus kereskedelembe vetett fogyasztói bizalom közötti fő kapcsolatokat. Mint ahogy az 1. ábra szemlélteti, a szerzők négy fö lehetséges elözménycsoportot határoznak meg: az internetes kereskedő megbízhatósága, az internetes vásárlási közeg megbízhatósága, háttér (infrastrukturális) tényezők és egyéb tényezők. A modellben a képesség, az integritás és a jóindulat pedig következetesen kapcsolódik a bizalomhoz.

$\mathrm{Az}$ internetes vásárlás olyan tevékenység, amely feltétlenül magában foglalja az elsődleges interakciókat a számítógépes rendszerekkel. Bizonyos értelemben az internetes eszköz (pl. személyi számítógép, okostelefon), amellyel a fogyasztó kölcsönhatásba lép, bizonyos szempontból megegyezik a hagyományos üzletben lévő eladóval. $\mathrm{Az}$, hogy a fogyasztók mennyire bíznak ebben a számítógépes adathordozóban, valószínüleg befolyásolja az internetes vásárlás iránti általános bizalmukat.
A három bizalmi előzmény hatását befolyásolhatja az egyén bizalomra való hajlandósága. Lee és Turban (2001) szerint ez a tulajdonság függ a kulturális háttértől, a személyiség típusától és a fejlödés tapasztalataitól. Úgy vélik, hogy a bizalomra való hajlam olyan személyiségjegy, amely méri a megbízhatóság jellemzőinek a bizalom kialakulására gyakorolt hatását. A fogyasztók annak eldöntésekor, hogy bízzanak-e és mennyire a kereskedőben, jelzéseket keresnek (pl. a megbízhatósági tulajdonságok). Ugyanakkor a bizalmi-hajlandóság gyengítheti vagy felerősítheti ezeket a jeleket.

$\mathrm{Az}$ egyéb tényezők csoportja olyan komponenseket foglal magában, amelyek nem felelnek meg az előző kategóriáknak, de hatással lehetnek a fogyasztói bizalomra az internetes vásárlás iránt. Példa lehet erre az internetes üzlet mérete, a vásárlók különböző demográfiai változói (pl. nem, életkor) és az internethasználat tapasztalata (Lee \& Turban 2001).

Ez a bizalmi modell koherens keretet biztosít az internetes fogyasztói bizalom jelenségének empirikus kutatásához. A szerzők fő célja a tanulmányukban ismertetett bizalmi modell kidolgozásával 
az, hogy elősegítsék az elektronikus kereskedelem növekedésének felgyorsítását azáltal, hogy iránymutatást nyújtanak arra vonatkozóan, hogyan lehet eltávolítani a fejlődés egyik fő akadályát, azaz a bizalom hiányát.

Kutatásom során célom feltérképezni azokat a tényezőket, melyek napjainkban, azaz az online kereskedelem két évtizedes berobbanását követően fontos szerepet játszanak a fogyasztói bizalomérzet kialakulásában és erösödésében az elektronikus kereskedelem terén - ezzel kompenzálva a fizikai kapcsolat hiányát. Ennek tükrében kutatási kérdésem, hogy milyen tényezők növelik a fogyasztó bizalomérzetét az online vásárlások során.

A kutatási kérdés megválaszolása kvalitatív kutatás keretében mélyinterjús vizsgálat segítségével történik. A vizsgálati módszer kiválasztása során fö cél volt, hogy olyan bizalmi tényezők is felszínre kerüljenek, melyeket esetleg még egyetlen modell sem foglal magába. Összesen 17 mélyinterjú készült, melyek alanyai 25 és 35 év közötti nők, akik közül mindegyikükre jellemző a rendszeres, legalább heti rendszerességủ online vásárlás. A választás azért esett erre a korcsoportra, mert jellemzően megfelelő jövedelemmel és kellő ismeretekkel rendelkeznek a rendszeres online vásárláshoz. Az interjúk alanyai pedig azért csak nők, mert egyes kutatások eredménye szerint ${ }^{1}$ a férfiak „bátrabban” vásárolnak a virtuális boltokban, mint a nők. Továbbá, feltételezhetően a nők részletesebben kifejtik a háttérben meghúzódó okokat. Ezért vélhetően a női alanyoktól a mélyinterjúk során jobban megismerhetőbbé válnak a fogyasztói bizalomérzet befolyásoló tényezői. Az interjúkészítés időtartama 3 hónap volt.

Az interjú bevezetö kérdései arra irányultak, hogy a megkérdezett személy milyen gyakran vásárol online áruházakban; jellemzően csak a korábbi tapasztalatok alapján már ismert webáruházakból szokott-e rendelni, vagy gyakorlatilag változó, hogy mit honnan vásárol meg; illetve jellemzően pozitív vagy negatív tapasztalatai vannak elektronikus vásárlásai kapcsán. Ezt követően került sor az online boltok megbízhatóságának véleményezésére, a különböző weboldalakon fellelhető fogyasztói vélemények, értékelések elektronikus vásárlásra gyakorolt bizalomnövelő hatásának megismerésére; illetve annak feltárására, mitől válik megbízhatóvá egy online kereskedö, és a virtuális közeg mennyire lehet megbízható. A következö kérdés azt igyekezett feltárni, hogy a megkérdezett személyek hogyan vélekednek arról, hogy napjainkban már megvannak-e a megfelelő jogi keretek, szabályozások a megfelelő védelemhez; illetve hogyan ítélik meg saját magukat, rendelkeznek-e elegendő ismerettel ahhoz, hogy ne váljanak virtuális csalás áldozatává. Továbbá, ha egy ismeretlen weboldalról történik a rendelés, akkor mit néznek meg elöször, esetleg minek érdemes utána járni más weboldalak segítségével; figyelembe veszik-e a különböző árösszehasonító oldalakon fellelhető információkat, „feedback” értékeléseket; és milyen véleménnyel vannak a hitelesítő tanúsítványokról. Kérdésként merült fel az is, hogy mik azok a tényezők, melyek pozitív hatást gyakorolnak az online vásárlásokra, és ezáltal megnöveli a bizalmat a kereskedő felé; illetve mik azok a negatív tényezők, melyek hatására a megkérdezettek inkább nem rendelnek egy webáruházból. Utolsó kérdés pedig az volt, hogy mik azok az egyéb tényezők, melyek fontosak egy webáruház müködésében. Az interjú zárásaként pedig az interjúalanyok röviden összefoglalták, hogy számukra mivel tud egy online áruház bizalomnövelö hatással lenni.

\section{KUTATÁSI EREDMÉNYEK RESEARCH RESULTS}

\section{Egyén bizalomra való hajlandósága Individual trust propensity}

A virtuális világ napjainkra már olyan hatalmas mértékben egybeolvadt a hétköznapi élettel, hogy a fogyasztók számára gyakorlatilag természetessé vált az online felületeken keresztül történő vásárlás, szerződéskötés, szociális kapcsolattartás, és minden egyéb, melyre az internet lehetőséget biztosít. A digitális eszközök széles körü tárháza és könnyed megszerezhetősége átreformálta az adásvételt is. A vizsgálatban résztvevő 25 és 35 év közötti nők válaszaiból arra lehet következtetni, hogy míg egy évtizeddel ezelőtt a webáruházakból történő vásárlást kockázatosabbnak tartották a hagyományos vásárlásnál, addig mára ez a gyakran elektronikusan vásárlók körében megfordult, és sok esetben szívesebben vásárolnak meg egy terméket a világhálón keresztül.

Több válaszadó szerint ez elsősorban a 14 napos elállási joggal magyarázható, miszerint, ha a fogyasztónak bármi problémája akad a megvásárolt termékkel (vagy csak egyszerüen meggondolta magát és mégsem kell neki), a törvény 14 napot biztosít számára, hogy jelezze az online 
áruháznak, illetve kötelezi a kereskedőt a termék visszaküldését követően a vételár 14 napon belül történő visszafizetésére. Ennek tudata növeli a bizalomra való hajlandóságot, mivel a válaszadók úgy vélik, hogy „a jogszabályi keretek sokkal inkább védik a fogyasztó érdekeit az online vásárlás során, mint a hagyományos vásárlás esetében”. Az egyéni bizalomra való hajlandóságot vizsgáló interjúkérdésekre kapott válaszok arra is rávilágítottak, hogy a megkérdezettek bizalomra való hajlandóságát az is növeli, hogy az elektronikus vásárlások jellemzően pozitív élményt nyújtanak a vevőknek (pl. „jó vásárt csináltam, mert ennyiért máshol nem tudtam volna megvenni”, ,„örülök, hogy sikerült beszerezni, mert nálunk ezt nem lehet kapni egyik üzletben sem”). Az elmúlt évek kedvező tapasztalatai pedig felhalmozódtak, ami nem csak az egyén bizalomra való hajlandóságát növeli, hanem egyúttal az elektronikus kereskedőkbe vetett bizalmat is.

\section{E-kereskedők megbízhatósága Trustworthiness of internet merchant}

A kereskedők a bennük való megbízhatóságot leginkább az elégedett fogyasztók véleményével tudják elősegíteni, viszont ehhez egy-két pozitív vélemény a webáruház nyitólapján feltüntetve igen kevés, a vásárlók véleménye csak akkor van más, vásárolni szándékozó egyénre hatással, ha az nagyszámban érhető el - derült ki a válaszokból. Az egyik interjúalany erröl így vélekedett: „ha csak néhány vásárlótól olvasható értékelés $a z$ adott webáruházról, az olyan, mintha senki nem irt volna véleményt róla." Ez a pozitív és a negatív vásárlás utáni minősítésekre egyaránt igaznak mondható az interjúalanyok vélekedése szerint. Emellett, a vizsgálati eredmények arra is rámutatnak, hogy a szöveges véleményalkotás helyett a válaszadó 25 és 35 éves nők sokkal inkább figyelembe veszik az ún. feedback értékelést, azaz az öt fokozatú csillagozást. Ugyanakkor különbséget tesznek aközött, hogy hol olvassák ezeket. Például, ha egy több webáruházat feltüntető oldalon, akkor azt hitelesnek tartják, és növeli a kereskedő iránti bizalmukat, viszont, ha csak a kereskedő cég honlapján (pl. kezdőlapon) látják ezeket a fogyasztói visszajelzéseket, akkor azt már kevésbé ítélik hitelesnek, így az áruházba vetett bizalmukat sem növeli. Tehát itt jön be a szerepe a bizalom terén a különböző árösszehasonlító oldalaknak, mivel ezeken a fogyasztók nemcsak arról győződhetnek meg, mely webáruházakban mennyiért tudják az adott terméket megvásárolni, hanem arról is, hogy egy harmadik fél részére hogyan vélekednek azok az egyének az egyes kereskedőkről, akik már vásárlási tapasztalattal bírnak. Több interjúalanyt idézve: „ez pedig megkönnyiti a döntést.”

Elég sok olyan webáruházzal lehet találkozni, melyek domain neve .hu végződésü, magyar nyelvü, az árak forintban kerülnek feltüntetésre, de mégis külföldi cég által müködtetett online piactérről van szó. Ezekről az online kereskedőkről igencsak megoszlik a válaszadók véleménye. A megkérdezettek egy része sokkal kockázatosabbnak tartja azokat az online boltokat, melyek üzemeltetője nem Magyarországon bejegyzett cég, hanem Szlovákiában vagy Romániában. Erről az egyik interjúalany úgy vélekedett, hogy ,,inkább megveszem pár ezer forinttal drágában másik webshopból, csak magyar cég legyen, mert ha bármi probléma felmerül a vásárlás során, akkor itthon sokkal jobban tudom érvényesiteni a fogyasztói jogaimat. ” A válaszadók másik része viszont úgy véli, hogy rugalmasabbak a külföldi cégek, mint a hazaiak, ami jellemzően a gyors kiszállítási időben és a visszaküldött termék árának pár napos visszafizetésében mutatkozik meg. Utóbbit a legtöbben a jó szándék jelének tekintik, így a jövőben is vásárolnának az adott webáruháztól annak ellenére, hogy az adásvétel valamilyen okból kifolyólag mégsem jött létre.

Az e-kereskedők megbízhatóságának értékelésében érdekes módon még napjainkban is jelentős szerepe van a telefonos elérhetőségnek. Ez sokak számára a fizikai kapcsolat hiányát pótolja - derült ki a válaszokból. Ezt az egyik interjúalany úgy fogalmazta meg, hogy: „ha lehetöségem van rá, hogy egy élö emberrel beszéljek például reklamáció esetén, az olyan, mintha bemehetnék az üzletbe az eladóval beszélni." Tehát a fogyasztók közül sokan nem az általános szerződési feltételeket olvassák el, hanem megnézik, hogy van-e telefonszám feltüntetve a weboldalon az elérhetőségek között.

\section{A virtuális közeg megbízhatósága Trustworthiness of virtual medium}

Hasonlóan az online világba vetett bizalomhoz, a virtuális közegben való megbízhatóság is már tapasztalatokon alapszik, így a megkérdezett hölgyek is napjainkban már szinte teljes mértékben nyitottá váltak a digitális eszközhasználatra, egyben az online kereskedelemre. Az ismeretek kiszélesedése, a digitális közeg megértése pedig növeli a bizalomérzetet. „Minél jobban megismerjük a virtuális világ müködését, szabályozottságát, és minél jobban felismerjük a csalókat benne, annál inkább eggyé válunk vele." A válaszadók többsége úgy véli, hogy a technikai kompetenciák szinte már 
alap készségekké váltak, ami nagymértékben elősegítette a fogyasztók számára is a virtuális közeg megértését. Ezzel csökkent a veszélyérzetük, nőtt a bizalomra való hajlandóság, és egyre gyakoribbá váltak az elektronikus úton történő vásárlások. „Pár évnek el kellett telnie ahhoz, hogy rutinná váljon az online vásárlás.” A legtöbb fogyasztó úgy véli, hogy a virtuális közegben teljes mértékben meg lehet bízni, azonban „van pár játékszabály, amit be kell tartani a biztonság érdekében”.

\section{Háttér (infrastrukturális) tényezők Contextual (infrastructure) factors}

Az interjúalanyok válaszaiból kiderül, hogy a biztonsági infrastruktúra hatékonysága nincs bizalomnövelő hatással az online vásárlásaikra. Ennek okát az egyik megkérdezett nő úgy foglalta össze, hogy: „, a virtuális világban történő csalásokról, visszaélésekről és jogvitákról még annyit sem lehet hallani, mint a bolti lopásokról”. Ugyanakkor, a vizsgálatban résztvevők többsége úgy véli, hogy ha egy ismert szervezet tanúsítványát feltüntetik egy webáruház nyitó oldalán, akkor az növeli a bizalomérzetet a kereskedő cég iránt. Ez azzal magyarázható, hogy ,a legtöbb ilyen tanúsitvány megszerzése komoly feltételhez kötött, igy az oldalra látogatók számára már van egy hiteles vélemény (minősités)”, ez pedig értékkel bír. Többen megjegyezték, fontos azonban, hogy a tanúsítványt kiadó szervezet valamilyen hatóság legyen (pl. fogyasztóvédelem) vagy pedig valamilyen komoly, nemzetközileg elismert szervezet, ellenkezö esetben nem érne célt, és „csak egy ugyanolyan vásárlói vélemény lenne, mint amit bárki beirhat a webáruház oldalára”. Tehát a külső megerösítésnek bizalomnövelö hatása van, ha megfelelö szervezettől származik. „Ez többet érne, mint 1000 öt csillagos értékelés."

\section{Egyéb tényezök Other factors}

A vizsgálat során kapott válaszokból arra lehet következtetni, hogy a 25 és 35 év közötti nők körében az egyéb tényezők halmaza szinte egyénenként változó. Gyakori bizalomnövelő tényezőként hangzott el az, ha egy közeli ismerős vagy családtag ajánlja az adott online áruházat. „Jó, ha olyan embernek van pozitiv tapasztalata egy online áruházzal kapcsolatban, akit én is jól ismerek." Egyes vizsgálati alanyok a nagyobb kereskedö cégeket részesítik előnyben, de van, aki sokkal jobban megbízik a kisebb (mini) webshopokban.
Olyan válaszadó is van, aki leginkább azokban az online áruházakban bízik meg, melyek rendelkeznek hagyományos üzlettel is, ,mert igy legalább biztosra lehet tudni, hogy valóban létezik a cég”. Bizalomnövelő hatással bír egyeseknél még például az is, ha sürün találkoznak a webáruház reklámjával a közösségi médiában, vagy esetleg a televízióban. De olyan vizsgálati alany is van, akinek bizalomérzetét az növeli, ha ,, a webáruház a Google találati listájának az elsö oldalán szerepel”. Tehát az egyéb bizalomnövelö tényezők tárháza határtalan.

$\mathrm{Az}$ interjúk során leggyakrabban a részletes termékleírás került említésre. A megkérdezettek közel háromnegyede volt azon a véleményen, hogy számára „, bizalomnövelö hatású, ha a webáruházban kinált termékekről minden esetben részletes leirás olvasható”.

Az interjúk során kapott válaszok alapján összességében megállapítható, hogy a vizsgálati alanyokban, mint mai online fogyasztókban, sokkal inkább megvan a bizalomra való hajlandóság, mint amennyire azt a Lee \& Turban (2001) kutatás eredménye mutatta. Véleményem szerint ez azzal magyarázható, hogy egyre könnyebben elérhetővé vált, illetve kiszélesedett a fogyasztók számára az elektronikus vásárlás, így az elmúlt évek alatt jelentős tapasztalatra tehettek szert. Az e-kereskedők és a virtuális közeg megbízhatóságát tekintve a megkérdezettek pozitívan vélekedtek, jellemzően már rutinos virtuális barangolóknak tekintik magukat. Ugyanakkor szinte valamennyi megkérdezett úgy vélekedett, hogy azért óvatosnak, sok esetben gyanakvónak kell lenni annak érdekében, hogy ne essen a vásárló csalás áldozatává. A háttér (infrastrukturális) tényezők terén a vizsgálatban résztvevő személyek bizalomérzetét leginkább az növeli a vásárlás során, ha egy úgymond valódiságot igazoló harmadik személy is bekapcsolódik az adásvételbe.

A kutatás során alkalmazott Lee \& Turban (2001) modellben megjelenő egyéb tényezők inkább a demográfiai jellemzőkre élesedtek ki (pl. nem, kor), azonban a jelen kutatásban ezen tényezők halmaza gyakorlatilag egyénenként változik. A válaszadók között ennek ellenére leggyakrabban az tekinthető egyéb bizalomnövelő tényezőnek, ha olyan személy ajánlotta számukra az adott webáruházat, akit jól ismernek. 


\section{KÖVETKEZTETÉSEK CONCLUSIONS}

A kereskedelem létezése óta a tisztesség és a becsület fontos részét képezi az ügyleteknek. A piacgazdaság megerősödésével azonban a megfelelő, részletes törvényi szabályozás kisebb-nagyobb mértékben felváltotta a bizalom szerepét, és a kockázatcsökkenést már nem az érzékelt tisztességesség, becsületesség eredményezte, hanem az írott szerződés léte. A digitalizáció elterjedésével viszont a fizikális kapcsolatok hiánya miatt újra felerősödött a bizalom iránti igény - független attól, hogy a virtuális kereskedelemben létrejövő adásvételek is szerződésen alapulnak.

Tanulmányomban a fogyasztói bizalomérzetet befolyásoló tényezőket Lee és Turban (2001) modellje alapján vizsgáltam. A szerzőpáros abból indul ki, hogy az automatizált vagy számítógépes rendszerbe vetett emberi bizalom három tényezőtől függ: (1) a rendszer észlelt müszaki kompetenciától, (2) a rendszer észlelt teljesítményszintjétől és (3) az emberi operátor megértése a rendszer viselkedését irányító alapvető jellemzőkről és folyamatokról. A szerzők figyelembe vették azt is, hogy számos háttértényező fontos szerepet játszik a bizalomépítésben.

A vizsgálat alkalmával a 17 interjú kiértékelését követően kapott eredmények rámutatnak arra, hogy a fogyasztói bizalom kiépítése valóban fontos jelentőséggel bír az online áruházak sikeres müködésében, tehát a szerződéses kapcsolat - ellentétben a hagyományos kereskedelemmel - valóban nem tudja pótolni annak hiányát. Ugyanakkor a fentiekben bemutatott vizsgálat a 25 és 35 év közötti nők körére korlátozódik, így a kapott eredményekből az egész fogyasztói társadalomra nem lehet általános érvényü következtetéseket levonni - mint a Lee és Turban (2001) tanulmány esetében -, csak az adott célcsoportot ismerhetjük meg jobban a digitális bizalom szempontjából. Ennek ellenére, a kutatási eredmények egyértelmúen rámutatnak arra, hogy a bizalomépítés annyira felértékelödött a virtuális világban, hogy ha egy kereskedő nem fektet komoly hangsúlyt a fogyasztói bizalomérzet megteremtésére, az már akár rövidtávon forgalomcsökkenéssel járhat számára, mivel nem fog kellő számú megrendelés beérkezni webáruházába. Továbbá az sem mindegy, hogy a kereskedő a szükséges bizalmat hogyan akarja megteremteni, milyen online felületeket használ, illetve milyen eszközöket vet be, mivel nem minden járható megoldás hozza el a várt sikert. Lee és Turban (2001) kutatási eredményei azt mutatják, hogy a kereskedő integritása az internetes vásárlás iránti bizalom egyik legfontosabb pozitív tényezője, és ennek hatását az egyes fogyasztók bizalmi hajlandósága mérsékli.

Ezzel szemben, jelen tanulmány eredményei arra engednek következtetni, hogy napjainkban a 25 és 35 éves nők körében a háttér (infrastrukturális) tényezők szerepe felértékelődött, az egyes fogyasztók bizalmi hajlandósága pedig növeli az internetes vásárlás iránti bizalmat. Az interjúk válaszai rávilágítanak arra, hogy semmilyen tényező nem tudja pótolni (az online kereskedelemben sem) a korábbi vásárláson alapuló tapasztalatból kialakuló bizalmat, a törvényi szabályozások által nyújtott biztonságérzetet és a technikai kompetenciák alapkészségekké válását. E három tényező kialakulásához pedig az elmúlt két évtizedben végbemenő folyamatokhoz volt szükség. Míg az ezredforduló derekán a fö bizalmi tényezöket - az ekkor még ismeretlen - rendszer észlelt múszaki kompetenciái és észlelt teljesítményszintje jelentette, addig napjainkban már sokkal inkább a tapasztalatokon alapuló minősítések és a jogszabályi keretrendszerek jelentik. Ezért célszerú az online értékesítéssel foglalkozó kereskedöknek minél több árösszehasonlító oldalon feltünniük termékeikkel, mert ezek a weboldalak egyrészt lehetőséget biztosítanak a vásárlóknak, hogy megoszthassák tapasztalataikon alapuló véleményeiket más vásárlókkal az egyes termékekröl, másrészt pedig a fogyasztók ezeket az online oldalakat hiteles harmadik félként tekintik, így növeli bennük a bizalomérzetet az e-kereskedő iránt.

Jelen kutatási eredmények az egyik pillérjét jelentik jövőbeni kutatásaimnak, mely során azt kívánom feltárni, hogyan határozható meg a kreatív ipar digitális transzformációja a fogyasztói bizalomérzet befolyásoló tényezőinek hálójában. Következő lépésben a KKV-szektor oldaláról azt vizsgálom, hogy milyen jellemzők azonosíthatók a kreatív ipar digitális transzformációjában a fogyasztói bizalomérzet megteremtése és annak növelése érdekében. 


\section{HIVATKOZÁSOK REFERENCES}

Aranyossy M., Magisztrák B. (2016), A vásárlói bizalom hatása az e-kereskedelmi vásárlási hajlandóságra (Magyar-lengyel összehasonlító vizsgálat), Marketing \& Menedzsment, 50(3-4), 73-87

Balogh G. (2006), Egy túlterhelt fogalom, Információs Társadalom, 6(1), 22-29

Bányai E., Novák P. (2011), Online üzlet és marketing, Budapest, Akadémiai Kiadó

Beldad, A., De Jong, M. and Steehouder, M. (2010), "How shall I trust the faceless and the intangible? A literature review on the antecedents of online trust", Computers in Human Behavior, 26(5), 857-869, DOI: 10.1016/j. chb.2010.03.013

Gere, C. (2004), Digital Culture, London, Reaktion Books

Grant, I. and Waite, K. (2013), Online privacy: concepts, issues and research avenues for digital consumption, In Belk, R. W. and Llamas, R. (Eds.), The Routledge companion to digital consumption, Routledge, 333-345

Hámori B. (2003), Érzelemgazdaságtan - A közgazdasági elemzés kiterjesztése, Budapest, Kossuth Kiadó

Hámori B. (2004), „Bizalom, jóhírnév és identitás az elektronikus piacokon", Közgazdasági Szemle, 51(9), 832-848

Iványi M. (2015), „Megtévesztés, színlelt attitűd és a közösségi média", Médiakutató, XVI(2), $15-24$

KSH (é.n.), A kiskereskedelmi üzletek forgalma üzlettípusonként (2000-), http://www.ksh.hu/ docs/hun/xstadat/xstadat_eves/i_okfa002b.html (Letöltés dátuma: 2020. május 21 .)
Lee, M. K. O. and Turban, E. (2001), ”A Trust Model for Consumer Internet Shopping", International Journal of Electronic Commerce, 6(1), 75-91, DOI: 10.1080/10864415.2001.11044227

Stewart, K. J. (2003), "Trust transfer on the world wide web", Organization Science, 14(1), 5-17, DOI: $10.1287 /$ orsc. 14.1.5.12810

Szabó K. - Hámori B. (2006), Információgazdaság, Budapest, Akadémiai Kiadó

Verebics J. (2001), Elektronikus gazdasági kapcsolatok joga, Budapest, HVG-ORAC

Zucker, L. G. (1986), ’Production of Trust: Institutional Sources of Economic Structure, 18401920", Research in Organizational Behaviour, 8, 53-111 
Csonka-Ambrus Ágnes, PhD hallgató csonka.ambrus.agnes@eco.u-szeged.hu

Szegedi Tudományegyetem

\section{Factors that influence the consumer's sense of trust in e-commerce}

\section{THE AIM OF THE PAPER}

In buy-and-take in the virtual world, all forms of physical contact are missing, resulting in an appreciation of trust factors. In my study, I examine what are the trust factors that can replace physical contact and thus increase consumer confidence in the merchant today, following the decade-long explosion of online commerce.

\section{METHODOLOGY}

Based on the model proposed by Lee and Turban (2001), I examine what factors may influencing consumer confidence in online commerce. The authors identify four main areas: the reliability of an online merchant; the reliability of the Internet as a medium of purchase; infrastructural factors and other factors. These variables are moderated by the individual consumer's willingness to trust.

\section{MOST IMPORTANT RESULT}

The feeling of trust that develops in e-shopping is mostly influenced by the experience gained over many years. And the widespread use of digital devices has made it possible to develop technical competencies, which will also significantly increase consumer confidence in e-commerce when shopping. Practical experience can only be partially replaced by certain trust factors (feedback evaluation, telephone customer service, etc.). In the absence of these, the inclusion of a certificate issued by a third party (office or internationally recognized organization) on the opening page of a web store might be able to replace this, i.e. increase consumer confidence in the trader.

\section{RECOMMENDATIONS}

Based on the research results, I believe that the best way to gain the trust of potential customers of a web store is to allow customers to share their experiences, for example on various price comparison pages, to provide detailed descriptions of their products and to allow consumers to contact them by phone.

Keywords: e-commerce, consumer trust, consumer behavior 